\title{
The Management of Penetrating Aortic Ulcer
}

\author{
Safa Salim ${ }^{1} * \mathbb{C}$, Matthew Machin ${ }^{1}$, Benjamin O. Patterson ${ }^{2}$ and Colin Bicknell ${ }^{1}$ \\ 1 Department of Surgery and Cancer, St. Mary's Hospital, Imperial Vascular Unit, Imperial College London, \\ London W2 1NY, UK; matthew.machin12@imperial.ac.uk (M.M.); colin.bicknell@imperial.ac.uk (C.B.) \\ 2 University Hospital Southampton, NHS Foundation Trust, Southampton SO16 6YD, UK; \\ Benjamin.Patterson@uhs.nhs.uk \\ * Correspondence: safa.salim11@imperial.ac.uk
}

Received: 23 April 2020; Accepted: 14 May 2020; Published: 15 May 2020

check for updates

\begin{abstract}
Penetrating aortic ulceration (PAU) is part of the spectrum of acute aortic syndromes (AAS), and is defined as an ulcerated intimal disruption due to atherosclerotic disease. PAU may be simple, isolated and asymptomatic, or it may be symptomatic, aneurysmal and extensive; these may progress and lead to rupture. This review aims to evaluate the treatment options for PAU. Treatment options range from radiological surveillance, risk factor modification, best medical therapy and open or endovascular surgical repair. Patients with PAU are frequently older and comorbid with relatively damaged aortic tissue; this can make open surgical repair more challenging. Endovascular repairs for larger, symptomatic, aneurysmal PAU may be performed with acceptable outcomes. Complex endovascular repairs may be required depending on the pathology. Patients with small, asymptomatic, uncomplicated PAU may be safely followed up with surveillance. PAU with concomitant intramural haematoma (IMH) should be closely monitored to observe for resolution or progression following conservative and medical management strategies. PAU is a unique entity and its natural history should be studied independently to better understand appropriate management strategies. This research is currently lacking, and larger studies or registries may be helpful in optimising PAU management.
\end{abstract}

Keywords: aortic disease; aorta; thoracic; acute aortic syndromes; penetrating aortic ulcer; penetrating atherosclerotic ulcer

\section{Background}

Penetrating aortic/atherosclerotic ulceration (PAU) is defined as an ulcerated, intimal disruption due to atherosclerotic disease [1]. It is radiologically identified as a focal outpouching of contrast extending beyond the intima (Figure 1) [2]. This article discusses the natural history and current best practice in managing this unique disease, and seeks to evaluate the available evidence and current guidance in the management of PAU.

\section{Natural History and Presentation}

PAU fits into a spectrum of acute aortic syndromes (AAS) consisting of classical dissection, intramural haematoma (IMH), limited dissection and iatrogenic/traumatic transection (Figure 2) [3].

PAU may be located in the ascending aorta (Type A PAU), in the descending thoracic aorta (Type B PAU) or abdominal aorta. It is radiologically distinct from other AAS, such as aortic dissection (AD) [2].

Simple isolated PAU may be asymptomatic and incidentally detected through imaging or may present with chest, back or abdominal pain [4,5]. Rarer presentations include Ortner's syndrome (recurrent laryngeal nerve palsy due to aortic pathologies), haemopericardium [6] and haemoptysis [7,8]. An estimated $20 \%-54 \%[9,10]$ of PAU patients are symptomatic. Simple isolated asymptomatic PAU may not progress and may go through a process of repair; however, the presence of symptoms is 
concerning. Significant disruption of the aortic wall causes aneurysmal degeneration, which can lead to a saccular or pseudoaneurysm [11]. Symptomatic, extensive, aneurysmal PAU is thought to have an increased risk of rupture; the exact rupture risk is unclear, however, it has been estimated that approximately $14 \%-40 \%$ of patients present or go on to rupture $[9,12-14]$.

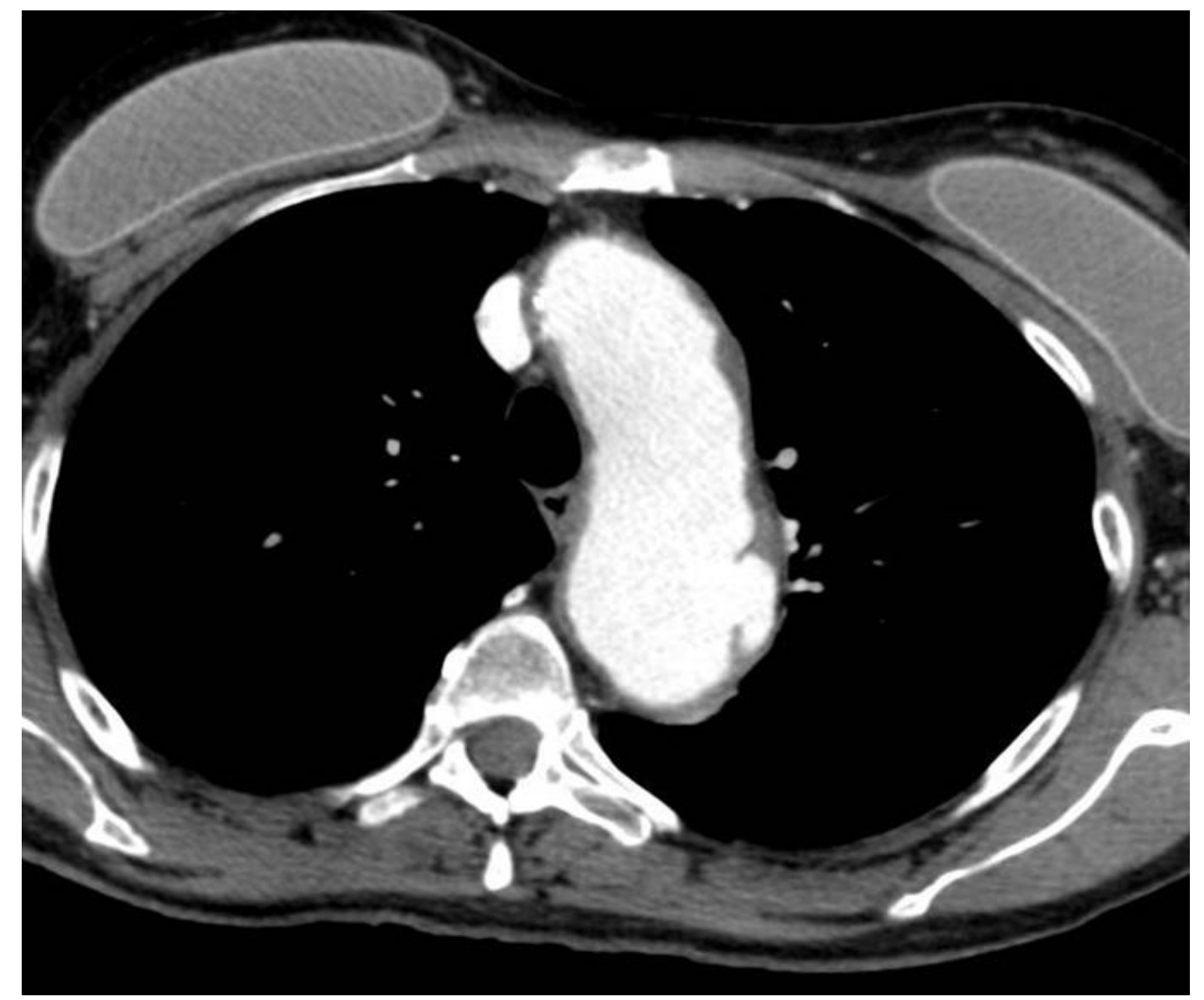

Figure 1. Axial computed tomography (CT) image of a thoracic penetrating aortic ulceration (PAU).

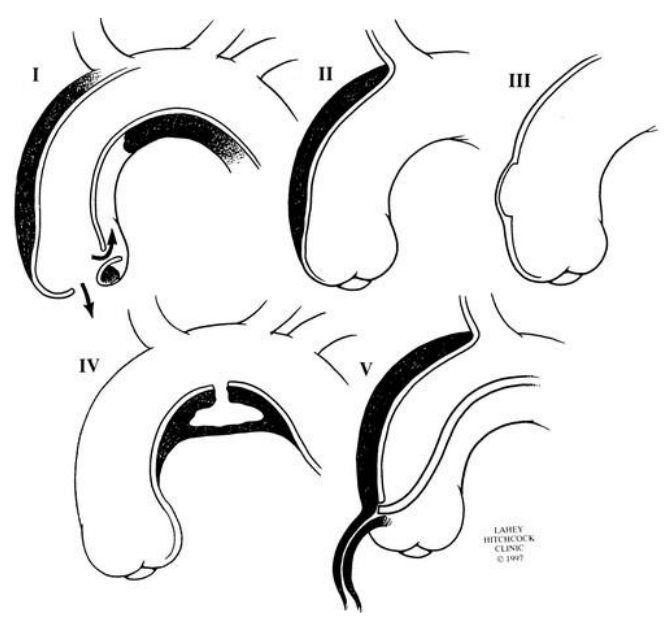

Figure 2. Spectrum of acute aortic syndromes (AAS), ranging from I: classic dissection, II: intramural hematoma (IMH), III: limited dissection, IV: PAU and V: iatrogenic/traumatic dissection [3].

It is hypothesised that continued erosion of the aortic wall in PAU may lead to disruption of the vasa vasorum and IMH, if there is secondary intimal disruption and extended longitudinal haematoma of the aortic wall $[11,15]$. For this reason, AAS may be seen in conjunction with each other. The proportion of PAU associated with IMH varies in the literature ranging from 9\%-14\% $[10,12,16]$ to $48 \%-60 \%$ [17-19]. In this article, isolated PAU is defined as a PAU without concomitant IMH or 
AD. The natural history and management of PAU has previously been studied by pooling together patients with and without concomitant IMH, making the natural history of an isolated PAU difficult to ascertain.

\section{Treatment of PAU}

PAU should be treated as a distinct clinical entity as it differs from AD and aneurysm scenarios in important ways. PAU often occurs in elderly, unfit patients with severe hypertension and with profound atherosclerotic disease [20]. Extensive plaque may rupture leading to IMH and AD.

There are no randomised trials evaluating treatment strategies for isolated PAU and PAU associated with IMH [21]. Frequently adopted interventions include radiological surveillance, antihypertensive therapy, open surgical repair and thoracic endovascular aortic repair (TEVAR) [10]. Effective management of PAU is vital, given the potential for progression to $\mathrm{AD} \mathrm{[22],} \mathrm{aneurysms} \mathrm{[23]} \mathrm{or} \mathrm{rupture} \mathrm{[24,25].}$

\subsection{Conservative and Medical Management}

Conservative management strategies include radiological surveillance and antihypertensive therapy with beta blockers [26]. There are a proportion of patients who may receive no specific management for their PAU [10,27].

At our institution, patients with smaller, asymptomatic, less aneurysmal PAU may be managed safely using a conservative approach [28]. These patients were managed with lifestyle and cardiovascular risk modification, including optimisation of blood pressure control, discussion at a multidisciplinary team meeting and annual computed tomography (CT) scanning. In another unit, patients with asymptomatic PAU were managed expectantly; none required surgical intervention, and none died of aortic complications at a median follow up of 457 days [29]. Although asymptomatic patients may be managed conservatively, some ulcers become aneurysmal or grow in size [30]; it is estimated that $30 \%$ of medically managed PAU worsens [13]. In our experience, $14 \%$ of those initially managed conservatively subsequently required surgical repair for aneurysmal degeneration [28]. It has previously been suggested that early intervention should be considered in PAU with a maximum diameter of more than $20 \mathrm{~mm}$ [31].

These findings highlight the importance of surveillance in medically managed PAU, although there is evidence to suggest this is not always adequately performed [32]. This is needed to evaluate evolution of disease and personalise management strategies. Guidance for surveillance following treatment states that a CT or MRI should be performed prior to hospital discharge, at 1, 3 and 6 months, and yearly thereafter [26].

It is thought that PAU complicated by IMH may be more likely to progress [31], hence guidelines suggest that endovascular/surgical repair should be considered for PAU with concomitant IMH. However, in a series of 105 PAU patients, both with and without IMH, it was concluded that many PAUs may be treated conservatively with surveillance [20]. This may suggest that patients with concomitant IMH should be monitored closely in the first few months, to evaluate if the IMH is resolving with conservative management strategies. A strategy of initial surveillance for isolated thoracic and abdominal PAU is safe and effective with surgical intervention if there is radiological or clinical progression [16].

Conservative management may be suitable for more comorbid patients, as the long-term all-cause mortality in PAU patients is high. This may be attributable to significant comorbidities in these patients [12], so consideration of these factors should therefore play an important role in management decisions.

\subsection{Open Repair}

Strategies for the open repair of PAU are varied, depending on the location and presentation of the PAU; patients may also require extracorporeal perfusion [33]. Since PAU often occurs in older patients with atherosclerotic disease [10,14], these patients are at high risk during open surgery [34].

Outcomes and recommendations for open repair are mostly based on case series and case reports. One series reported a comparison between open descending aortic repair $(n=37)$ with TEVAR $(n=58)$ for PAU [35]. Early mortality was significantly higher in open repair (16.2\%) than in TEVAR (5.1\%). 
The causes of mortality following open repair included stroke, intraoperative myocardial infarction, bowel infarction and iatrogenic aorto-oesophageal fistulation [35]. The perioperative stroke rates were significantly higher in open repair (16.2\%) than TEVAR (3.4\%). Spinal cord ischaemia occurred in both open and endovascular repairs, but was permanent in patients with open repairs and recoverable in those who underwent TEVAR [35]. In this patient cohort, type of repair did not affect late mortality rates [35]. In another series, endovascular repair was associated with lower morbidity, although mortality rates were comparable [36]. Open repairs are more frequently performed for Type A PAU; tube grafts [37], chimney grafts [38] and frozen elephant trunk procedures [39] have been reported.

At our institution, only $6 \%$ of proximal PAU procedures were performed through an open repair [28]. Aortic tissue in patients with PAU may be thin and damaged making open graft repairs difficult. This, along with the focal nature of PAU, makes endovascular repair more attractive [26].

\subsection{Endovascular Repair}

Endovascular repair may be a less invasive alternative to open surgery and is widely studied with a range of available endografts.

At our institution, patients with larger, symptomatic or aneurysmal PAU predominantly underwent endovascular repair [28] with acceptable long-term outcomes. This is the case at other institutions, where patients with symptomatic PAU or concomitant AAS were more likely to undergo an operation [29].

Endovascular technical success has been reported at, or close to, $100 \%$ in a number of studies [5,9,40,41]. In hospital/30-day mortality post TEVAR for PAU is estimated at $4.8 \%$ [42]. Overall survival at 1, 5 and 10 years has been reported at 93\% [41,43], 72\%-84\% [41,43,44] and 60\%-70\% [41,43], respectively [42], which is reflective of the comorbidities in patients with PAU. The long term aortic-related survival rates have been reported between $96 \%-100 \%[40,42,43]$.

Endoleaks are reported in approximately $8 \%$ of cases $[42,43]$. Re-intervention rates were found to be 5\% [4,44] and lower in PAU (4.8\%) than with other AAS (TBD and IMH) [44]. The most common cause of re-intervention was type I endoleak [44]. Spinal cord ischaemia rates have been reported between $1.4 \%-3.4 \%$ [35,43]; the risk of spinal cord ischaemia may be less in PAU then other AAS [45], possibly due to their focal nature. The estimated perioperative stroke risk is $2.4 \%$ [42].

It is important to be prepared for more complex intervention when undertaking an endovascular repair. For instance, there may be problems with endovascular access through the iliac vessels, due to widespread atherosclerotic disease in PAU patients with an additional risk of distal embolization from atherosclerotic plaque rupture. Left ventricular transapical $[46,47]$ and carotid $[48,49]$ access have been described when inadequate iliofemoral access has been encountered. Complex interventions may also be required, because PAU is more frequently found in the arch, distal to the left subclavian or renal arteries, and therefore may require supra aortic debranching procedures, fenestrated or branched stents. The need for these more extensive interventions should be balanced against the benefit that is likely to be achieved, given that the peri-procedural risks will be greater.

It has been suggested that patients undergoing endovascular repair for acute or contained ruptures associated with PAU had improved survival compared to those with TAA or AD as the primary aetiology [50], this may be because the focal nature of PAU means that the proximal and distal sealing zones are more favourable.

\subsection{Surgical Management of Type A, Type B and Abdominal PAU}

PAU has classically been described in the descending thoracic aorta [12,51], however, a significant number may also be found in the aortic arch [28]. A recent series of 106 PAUs identified that $54 \%$ were found in the arch, $23 \%$ in the descending thoracic aorta and $24 \%$ in the abdomen [10]. The management of PAU differs depending on its location. European guidelines suggest that surgery should be considered for Type A PAU [21]. American guidelines state that emergency surgery should be considered in lesions affecting the ascending aorta [26]. AAS affecting the ascending aorta are associated with increased mortality [52] and rupture [2]. 
A number of small series demonstrate the use of endovascular repair for arch and Type A PAU [53,54]. A European registry for endovascular repair of arch PAU reported an 86\% overall 30-day survival rate [55]. There are fewer studies evaluating endovascular repair of Type A PAU compared to Type B PAU and, until recently, there was less technology available for Type A endovascular repair. Therefore, contemporary evaluation of outcomes in these patients is required.

Abdominal PAU may be at low risk of causing symptoms and progression [27,32] and, therefore, may be frequently detected incidentally, managed conservatively or not at all [32]. If performed, endovascular and open surgical repair of abdominal PAU appears to be safe and effective [56-59], including for complicated PAU [58] and para-visceral PAU, requiring fenestrated/branched endografts [60].

\subsection{Management of PAU Occurring with IMH}

European recommendations (Class II, Level C) suggest that TEVAR or surgery should be considered for a complicated Type B PAU, which includes PAU with IMH [21]. PAU with simple, limited stable IMH can be treated conservatively, and this may completely remodel over time. Patients who do not remodel and instead develop a true dissection with a patent true and false lumen, can be treated with early stenting to induce remodelling, or they can be treated with surveillance and only undergo endovascular repair if late dilatation occurs. The arguments for and against early stenting of type B aortic dissection are outside the remit of this discussion, but have been investigated elsewhere [61].

PAU/IMH patients that develop complications, such as rupture, malperfusion or have ongoing pain or uncontrolled hypertension after 3 days, should undergo treatment, usually by TEVAR.

Many studies reporting the natural history and management outcomes of patients with PAU, have included both patients with and without concomitant IMH $[4,5,12,17,19,62,63]$. In some studies, the presence of an IMH has been reported as having no significant impact on survival $[19,64]$. The extent of haematoma seems not to predict failure of medical therapy for PAU [20], but the presence of IMH may be associated with PAU treatment failure with TEVAR [65].

As we have outlined above, IMH with PAU may be treated conservatively. However, in this scenario, progression over time to type B aortic dissection may be more likely than when there is IMH alone [31].

As with isolated PAU, IMH secondary to PAU has a higher association with atherosclerotic disease than with other AAS [2]; significant cardiovascular comorbidity in this cohort may impact management decisions and the outcome of treatment.

\section{Conclusion}

PAU is a unique entity and should be studied independently to understand the natural history. The body of research in AAS is building, however, an understanding of the natural history and best management strategies of PAU are still disputed. This may be, in part, due to a lack of research that distinguishes PAU as a separate entity from PAU in combination with other AAS.

Treatment strategies are not well established, but it is accepted that conservative management for small, non-aneurysmal, asymptomatic PAU is best. For complicated PAU that requires treatment, endovascular management should be used but may require extra-anatomical bypass procedures. Surgery is feasible, but PAU patients are often old and frail with atherosclerotic disease.

Where there is concomitant PAU and IMH, surveillance may be used in the first instance. As with acute dissection, complicated PAU/IMH may require endovascular repair. However, the changing landscape and weight of evidence for early treatment of IMH with TEVAR may lead to a change in practice.

Research is lacking and often the number of patients included in each study is small, meaning that conclusions drawn from these studies may not be generalisable. Larger studies evaluating the treatment strategies of PAU may be required. Alternatively, a prospective database or registry of PAU patients may be helpful with different institutions reporting treatments and outcomes of patients with PAU [66]. 
Author Contributions: Conceptualisation, C.B.; writing-original draft preparation, S.S.; writing-review and editing, C.B., B.O.P., M.M.; supervision, C.B. All authors have read and agreed to the published version of the manuscript.

Funding: Infrastructure support for this work was provided by the NIHR Imperial Biomedical Research Centre, grant number: b69139.

Acknowledgments: Written on behalf of the Imperial Vascular Unit Collaborators. Infrastructure support for this work was provided by the NIHR Imperial Biomedical Research Centre.

Conflicts of Interest: The authors declare no conflict of interest.

\section{References}

1. Stanson, A.W.; Kazmier, F.J.; Hollier, L.H.; Edwards, W.D.; Pairolero, P.C.; Sheedy, P.F.; Joyce, J.W.; Johnson, M.C. Penetrating atherosclerotic ulcers of the thoracic aorta: Natural history and clinicopathologic correlations. Ann. Vasc. Surg. 1986, 1, 15-23. [CrossRef]

2. Coady, M.A.; Rizzo, J.A.; Elefteriades, J.A. Pathologic variants of thoracic aortic dissections: Penetrating atherosclerotic ulcers and intramural hematomas. Cardiol. Clin. 1999, 17, 637-657. [CrossRef]

3. Svensson, L.G.; Labib, S.B.; Eisenhauer, A.C.; Butterly, J.R. Intimal tear without hematoma: An important variant of aortic dissection that can elude current imaging techniques. Circulation 1999, 99, 1331-1336. [CrossRef] [PubMed]

4. Brinster, D.R.; Wheatley, G.; Williams, J.; Ramaiah, V.; Diethrich, E.B.; Rodriguez-Lopez, J.A. Are Penetrating Aortic Ulcers Best Treated Using an Endovascular Approach? Ann. Thorac. Surg. 2006, 82, 1688-1691. [CrossRef] [PubMed]

5. Dalainas, I.; Nano, G.; Medda, M.; Bianchi, P.; Casana, R.; Ramponi, F.; Stegher, S.; Malacrida, G.; Inglese, L.; Tealdi, D. Endovascular Treatment of Penetrating Aortic Ulcers: Mid-term Results. Eur. J. Vasc. Endovasc. Surg. 2007, 34, 74-78. [CrossRef] [PubMed]

6. Abdel-Gawad, E.A.; Housseini, A.M.; Ailawadi, G.; Maged, I.M.; Hagspiel, K.D. Hemopericardium caused by penetrating ulcer of the ascending aorta diagnosed by computed tomography angiography. J. Trauma Inj. Infect. Crit. Care 2010, 68, 1512. [CrossRef]

7. Avlonitis, V.S.; Bury, R.W.; Duncan, A.J.; Zacharias, J. Penetrating ulcer of the aortic arch presenting with hemoptysis. J. Thorac. Cardiovasc. Surg. 2009, 137, e10-e12. [CrossRef]

8. Fukushima, M.; Seino, Y.; Yoshikawa, M.; Ueda, Y.; Takano, T. A case of penetrating aortic atherosclerotic ulcer with hemoptysis. Jpn. Heart. J. 2000, 41, 781-785. [CrossRef]

9. Fiorucci, B.; Kölbel, T.; Rohlffs, F.; Heidemann, F.; Carpenter, S.W.; Debus, E.S.; Tsilimparis, N. The role of thoracic endovascular repair in elective, symptomatic and ruptured thoracic aortic diseases. Eur. J. Cardio. Thoracic Surg. 2019, 56, 197-203. [CrossRef]

10. Gabel, J.; Tomihama, R.T.; Abou-Zamzam, A.M.; Nekrasov, V.; Oyoyo, U.E.; Bianchi, C.; Teruya, T.H.; Kiang, S.C. Early Surgical Referral for Penetrating Aortic Ulcer Leads to Improved Outcome and Overall Survival. Ann. Vasc. Surg. 2019, 57, 29-34. [CrossRef]

11. Bicknell, C.; Powell, J.T. Intramural haematoma remains an enigma. Eur. Hear. J. 2019, 40, 2737-2739. [CrossRef] [PubMed]

12. Geisbüsch, P.; Kotelis, D.; Weber, T.F.; Hyhlik-Dürr, A.; Kauczor, H.-U.; Böckler, D. Early and midterm results after endovascular stent graft repair of penetrating aortic ulcers. J. Vasc. Surg. 2008, 48, 1361-1368. [CrossRef] [PubMed]

13. Chou, A.S.; Ziganshin, B.A.; Charilaou, P.; Tranquilli, M.; Rizzo, J.A.; Elefteriades, J.A. Long-term behavior of aortic intramural hematomas and penetrating ulcers Read at the 95th Annual Meeting of the American Association for Thoracic Surgery, Seattle, Washington, April 25-29, 2015. J. Thorac. Cardiovasc. Surg. 2016, 151, 361-373. [CrossRef] [PubMed]

14. Coady, M.A.; Rizzo, J.A.; Hammond, G.L.; Pierce, J.G.; Kopf, G.S.; Elefteriades, J.A. Penetrating ulcer of the thoracic aorta: What is it? How do we recognize it? How do we manage it? J. Vasc. Surg. 1998, 27, 1006-1015. [CrossRef]

15. Eggebrecht, H.; Plicht, B.; Kahlert, P.; Erbel, R. Intramural Hematoma and Penetrating Ulcers: Indications to Endovascular Treatment. Eur. J. Vasc. Endovasc. Surg. 2009, 38, 659-665. [CrossRef] 
16. Gifford, S.M.; A Duncan, A.; Greiten, L.E.; Gloviczki, P.; Oderich, G.S.; Kalra, M.; Fleming, M.D.; Bower, T.C. The natural history and outcomes for thoracic and abdominal penetrating aortic ulcers. J. Vasc. Surg. 2016, 63, 1182-1188. [CrossRef]

17. Eggbrecht, H.; Herold, U.; Schmermund, A.; Lind, A.; Kuhnt, O.; Martini, S.; Kühl, H.; Kienbaum, P.; Peters, J.; Jakob, H.; et al. Endovascular stent-graft treatment of penetrating aortic ulcer: Results over a median follow-up of 27 months. Am. Hear. J. 2006, 151, 530-536. [CrossRef]

18. Girn, H.; McPherson, S.; Nicholson, T.; Mavor, A.; Homer-Vanniasinkam, S.; Gough, M. Short series of emergency stent-graft repair of symptomatic penetrating thoracic aortic ulcers (PTAU). Vasc. Med. 2009, 14, 123-128. [CrossRef]

19. Janosi, R.A.; Gorla, R.; Tsagakis, K.; Kahlert, P.; Horacek, M.; Bruckschen, F.; Dohle, D.S.; Jakob, H.; Schlosser, T.; Eggebrecht, H.; et al. Thoracic endovascular repair of complicated penetrating aortic ulcer: An 11-year single-center experience. J. Endovasc. Ther. 2016, 23, 150-159. [CrossRef]

20. Cho, K.R.; Stanson, A.W.; Potter, D.; Cherry, K.J.; Schaff, H.V.; Sundt, T.M. Penetrating atherosclerotic ulcer of the descending thoracic aorta and arch. J. Thorac. Cardiovasc. Surg. 2004, 127, 1393-1401. [CrossRef]

21. Erbel, R.; Aboyans, V.; Boileau, C.; Bossone, E.; Bartolomeo, R.D.; Eggebrecht, H.; Evangelista, A.; Falk, V.; Frank, H.; Gaemperli, O.; et al. 2014 ESC Guidelines on the diagnosis and treatment of aortic diseases: Document covering acute and chronic aortic diseases of the thoracic and abdominal aorta of the adult. The Task Force for the Diagnosis and Treatment of Aortic Diseases of the European Society of Cardiology (ESC). Eur. Heart J. 2014, 35, 2873-2926. [PubMed]

22. Giri, S.; Dhakal, P.; Hwang, I.; Siwakoti, K.; Alsafwah, S. Penetrating aortic ulcer leading to aortic dissection. JAAPA Off. J. Am. Acad. Physician Assist. 2017, 30, 23-25. [CrossRef] [PubMed]

23. Eggbrecht, H.; Baumgart, D.; Schmermund, A.; Herold, U.; Hunold, P.; Jakob, H.; Erbel, R. Penetrating atherosclerotic ulcer of the aorta: Treatment by endovascular stent-graft placement. Curr. Opin. Cardiol. 2003, 18, 431-435. [CrossRef] [PubMed]

24. Ando, Y.; Minami, H.; Muramoto, H.; Narita, M.; Sakai, S. Rupture of thoracic aorta caused by penetrating aortic ulcer. Chest 1994, 106, 624-626. [CrossRef]

25. Chenesseau, J.; Barral, P.-A.; Piquet, P.; Gaudry, M. A ruptured penetrating atherosclerotic ulcer of the ascending aorta: A case report of an endovascular repair with extending the length of the aortic coverage by debranching the innominate artery. Eur. Hear. J. Case Rep. 2019, 3, ytz043. [CrossRef]

26. Hiratzka, L.F.; Bakris, G.L.; Beckman, J.A.; Bersin, R.M.; Carr, V.F.; Casey, D.E., Jr.; Eagle, K.A.; Hermann, L.K.; Isselbacher, E.M.; Kazerooni, E.A.; et al. 2010 ACCF/AHA/AATS/ACR/ASA/SCA/SCAI/SIR/STS/SVM guidelines for the diagnosis and management of patients with Thoracic Aortic Disease: A report of the American College of Cardiology Foundation/American Heart Association Task Force on Practice Guidelines, American Association for Thoracic Surgery, American College of Radiology, American Stroke Association, Society of Cardiovascular Anesthesiologists, Society for Cardiovascular Angiography and Interventions, Society of Interventional Radiology, Society of Thoracic Surgeons, and Society for Vascular Medicine. Circulation 2010, 121, e266-e369.

27. Flohr, T.R.; Hagspiel, K.D.; Jain, A.; Tracci, M.C.; Kern, J.A.; Kron, I.L.; Cherry, K.J.; Upchurch, G.R., Jr. The natural history of penetrating ulcers of the iliac arteries. J. Vasc. Surg. 2016, 63, 399-406. [CrossRef]

28. Salim, S.; Locci, R.; Martin, G.; Gibbs, R.; Jenkins, M.; Hamady, M.; Riga, C.; Bicknell, C.; Collaborators, I.V.U.; Davies, A.; et al. Short- and long-term outcomes in isolated penetrating aortic ulcer disease. J. Vasc. Surg. 2020. [CrossRef]

29. Absi, T.S.; Sundt, I.T.M.; Camillo, C.J.; Schuessler, R.B.; Gutierrez, F.R. Penetrating atherosclerotic ulcers of the descending thoracic aorta may be managed expectantly. Vascular 2004, 12, 307-311. [CrossRef]

30. Harris, J.A.; Bis, K.G.; Glover, J.L.; Bendick, P.J.; Shetty, A.; Brown, O. Penetrating atherosclerotic ulcers of the aorta. J. Vasc. Surg. 1994, 19, 90-99. [CrossRef]

31. Ganaha, F.; Miller, D.; Sugimoto, K.; Do, Y.S.; Minamiguchi, H.; Saito, H.; Mitchell, R.S.; Dake, M.D. Prognosis of aortic intramural hematoma with and without penetrating atherosclerotic ulcer: A clinical and radiological analysis. Circulation 2002, 106, 342-348. [CrossRef] [PubMed]

32. Flohr, T.R.; Hagspiel, K.D.; Jain, A.; Tracci, M.C.; Kern, J.A.; Kron, I.L.; Cherry, K.J.; Upchurch, G.R., Jr. The History of Incidentally Discovered Penetrating Aortic Ulcers of the Abdominal Aorta. Ann. Vasc. Surg. 2016, 31, 8-17. [CrossRef] [PubMed]

33. De Souza, D.G.; Blank, R.S.; Mazzeo, F.J.; Singh, K.E. Penetrating ascending aortic atherosclerotic ulcer. Anesth. Analg. 2009, 109, 1035-1037. [CrossRef] [PubMed] 
34. Czerny, M.; Funovics, M.; Ehrlich, M.; Hoebartner, M.; Sodeck, G.; Dumfarth, J.; Schoder, M.; Juraszek, A.; Dziodzio, T.; Loewe, C.; et al. Risk factors of mortality in different age groups after thoracic endovascular aortic repair. Ann. Thorac. Surg. 2010, 90, 534-538. [CrossRef]

35. Patel, H.J.; Sood, V.; Williams, D.M.; Dasika, N.L.; Diener, A.C.; Deeb, G.M. Late outcomes with repair of penetrating thoracic aortic ulcers: The merits of an endovascular approach. Ann. Thorac. Surg. 2012, 94, 516-523. [CrossRef]

36. Farber, M.; Lee, W.A.; Szeto, W.Y.; Panneton, J.M.; Kwolek, C.J. Initial and midterm results of the Bolton Relay Thoracic Aortic Endovascular Pivotal Trial. J. Vasc. Surg. 2017, 65, 1556-1566. [CrossRef]

37. Kovacević, P.; Velicki, L.; Popović, D.; Ivanović, V.; Mojasević, R. Surgical treatment of penetrating atherosclerotic ulcer of the descending aorta. Vojnosanit. Pregl. 2013, 70, 874-877. [CrossRef]

38. Gehringhoff, B.; Torsello, G.; Pitoulias, G.A.; Austermann, M.; Donas, K. Use of chimney grafts in aortic arch pathologies involving the supra-aortic branches. J. Endovasc. Ther. 2011, 18, 650-655. [CrossRef]

39. Kokotsakis, J.N.; Tassopoulos, D.; Ttofi, J.; Harling, L.; Ashrafian, H.; Velissarios, K.; Kratimenos, T.; Anagnostou, S.; Athanasiou, T. Surgical repair of distal arch psendoaneurysm from ruptured penetrating aortic ulcer with the frozen elephant trunk technique. J. Cardiothorac. Surg. 2014, 9, 68. [CrossRef]

40. Baumgart, D.; Eggebrecht, H.; Herold, U.; Kuehl, H.; Piotrowski, J.; Niebel, W.; Jakob, H.-G.; Erbel, R. Underlying aortic pathology and clinical health status determine success of endovascular stent-grafting for descending thoracic aortic disease. Catheter. Cardiovasc. Interv. 2006, 67, 527-534. [CrossRef]

41. Gottardi, R.; Zimpfer, D.; Funovics, M.; Schoder, M.; Lammer, J.; Wolner, E.; Czerny, M.; Grimm, M. Mid-term results after endovascular stent-graft placement due to penetrating atherosclerotic ulcers of the thoracic aorta. Eur. J. Cardio-Thorac. Surg. 2008, 33, 1019-1024. [CrossRef]

42. D’Annoville, T.; Ozdemir, B.A.; Alric, P.; Marty-Ané, C.-H.; Canaud, L. Thoracic Endovascular Aortic Repair for Penetrating Aortic Ulcer: Literature Review. Ann. Thorac. Surg. 2016, 101, 2272-2278. [CrossRef] [PubMed]

43. Czerny, M.; Funovics, M.; Sodeck, G.; Dumfarth, J.; Schoder, M.; Juraszek, A.; Dziodzio, T.; Loewe, C.; Reineke, D.; Krähenbühl, E.; et al. Results after thoracic endovascular aortic repair in penetrating atherosclerotic ulcers. Ann. Thorac. Surg. 2011, 92, 562-566. [CrossRef] [PubMed]

44. Fairman, A.S.; Beck, A.W.; Malas, M.B.; Goodney, P.P.; Osborne, N.H.; Schermerhorn, M.L.; Wang, G.J. Reinterventions in the modern era of thoracic endovascular aortic repair. J. Vasc. Surg. 2019, 71, 408-422. [CrossRef] [PubMed]

45. Khoynezhad, A.; Donayre, C.E.; Bui, H.; Kopchok, G.E.; Walot, I.; White, R.A. Risk Factors of Neurologic Deficit After Thoracic Aortic Endografting. Ann. Thorac. Surg. 2007, 83, S882-S889. [CrossRef] [PubMed]

46. Allen, K.; Aggarwal, S.; Davis, J.R.; Laster, S.; Vamanan, K.; Borkon, A.M. Thoracic endovascular aortic repair of the ascending and descending thoracic aorta utilizing left ventricular transapical access. J. Vasc. Surg. 2016, 63, 153S-154S. [CrossRef]

47. Ghazy, T.; Mahlmann, A.; Ouda, A.; Hoffmann, R.T.; Weiss, N.; Matschke, K.; Kappert, U. The transapical approach for TEVAR. Innov. Technol. Tech. Cardiothorac. Vasc. Surg. 2014, 9, 161.

48. Afifi, R.; Salamon, T.; Manhaim, D.; Kvasha, V.; Karmeli, R. Endovascular Repair of Ruptured Aortic Penetrating Ulcer Via Carotid Artery. Ann. Vasc. Surg. 2009, 23, 536.e1-536.e3. [CrossRef]

49. Heidenreich, M.J.; Neschis, D.G.; Costanza, M.J.; Flinn, W.R. Endovascular repair of a penetrating thoracic aortic ulcer by way of the carotid artery. J. Vasc. Surg. 2003, 38, 1407-1410. [CrossRef]

50. Eggbrecht, H.; Schmermund, A.; Herold, U.; Baumgart, D.; Martini, S.; Kuhnt, O.; Lind, A.Y.; Kühne, C.; Kühl, H.; Kienbaum, P.; et al. Endovascular stent-graft placement for acute and contained rupture of the thoracic aorta. Catheter. Cardiovasc. Interv. 2005, 66, 474-482. [CrossRef]

51. Nathan, D.P.; Boonn, W.; Lai, E.; Wang, G.J.; Desai, N.; Woo, E.Y.; Fairman, R.M.; Jackson, B.M. Presentation, complications, and natural history of penetrating atherosclerotic ulcer disease. J. Vasc. Surg. 2012, 55, 10-15. [CrossRef] [PubMed]

52. Evangelista, A.; Isselbacher, E.M.; Bossone, E.; Gleason, T.G.; Eusanio, M.D.; Sechtem, U.; Ehrlich, M.; Trimarchi, S.; Braverman, A.C.; Myrmel, T.; et al. Insights From the International Registry of Acute Aortic Dissection. Circulation 2018, 137, 1846-1860. [CrossRef] [PubMed]

53. Bernardes, R.C.; Navarro, T.P.; Reis, F.R.; Lima, L.C.; Monteiro, E.L.; Procopio, R.J.; Botelho, F.E.; Dardik, A. Early experience with off-the-shelf endografts using a zone 0 proximal landing site to treat the ascending aorta and arch. J. Thorac. Cardiovasc. Surg. 2014, 148, 105-112. [CrossRef] [PubMed] 
54. Bosiers, M.J.; Donas, K.P.; Mangialardi, N.; Torsello, G.; Riambau, V.; Criado, F.J.; Veith, F.J.; Ronchey, S.; Fazzini, S.; Lachat, M. European Multicenter Registry for the Performance of the Chimney/Snorkel Technique in the Treatment of Aortic Arch Pathologic Conditions. Ann. Thorac. Surg. 2016, 101, 2224-2230. [CrossRef] [PubMed]

55. Böckler, D.; Brunkwall, J.; Taylor, P.; Mangialardi, N.; Hüsing, J.; Larzon, T.; Hyhlik-Dürr, A.; Gawenda, M.; Clough, R.; Ronchey, S.; et al. Thoracic Endovascular Aortic Repair of Aortic Arch Pathologies with the Conformable Thoracic Aortic Graft: Early and 2 year Results from a European Multicentre Registry. Eur. J. Vasc. Endovasc. Surg. 2016, 51, 791-800. [CrossRef] [PubMed]

56. Batt, M.; Haudebourg, P.; Planchard, P.-F.; Ferrari, E.; Hassen-Khodja, R.; Bouillanne, P.-J. Penetrating atherosclerotic ulcers of the infrarenal aorta: Life-threatening lesions. Eur. J. Vasc. Endovasc. Surg. 2005, 29, 35-42. [CrossRef]

57. Georgiadis, G.S.; Trellopoulos, G.; Antoniou, G.A.; Georgakarakos, E.; Nikolopoulos, E.S.; Pelekas, D.; Pitta, X.; Lazarides, M.K. Endovascular therapy for penetrating ulcers of the infrarenal aorta. ANZ J. Surg. 2013, 83, 758-763. [CrossRef] [PubMed]

58. Tsuji, Y.; Tanaka, Y.; Kitagawa, A.; Hino, Y.; Taniguchi, T.; Sugimoto, K.; Matsuda, H.; Okita, Y. Endovascular stent-graft repair for penetrating atherosclerotic ulcer in the infrarenal abdominal aorta. J. Vasc. Surg. 2003, 38, 383-388. [CrossRef]

59. Piffaretti, G.; Tozzi, M.; Lomazzi, C.; Rivolta, N.; Caronno, R.; Castelli, P. Endovascular repair of abdominal infrarenal penetrating aortic ulcers: A prospective observational study. Int. J. Surg. 2007, 5, 172-175. [CrossRef] [PubMed]

60. Gargiulo, M.; Ancetti, S.; Spear, R.; Gallitto, E.; Vento, V.; Faggioli, G.; Stella, A.; Haulon, S. Endovascular Treatment of Para-Visceral Penetrating Aortic Ulcers Using Fenestrated/Branched Endografts. Eur. J. Vasc. Endovasc. Surg. 2019, 58 (6 Suppl. 1), e181. [CrossRef]

61. Nienaber, C.A.; Kische, S.; Rousseau, H.; Eggebrecht, H.; Rehders, T.C.; Kundt, G.; Glass, A.; Scheinert, D.; Czerny, M.; Kleinfeldt, T.; et al. Endovascular repair of type B aortic dissection: Long-term results of the randomized investigation of stent grafts in aortic dissection trial. Circ. Cardiovasc. Interv. 2013, 6, 407-416. [CrossRef]

62. Demers, P.; Miller, D.; Mitchell, R.S.; Kee, S.T.; Chagonjian, L.; Dake, M.D. Stent-graft repair of penetrating atherosclerotic ulcers in the descending thoracic aorta: Mid-term results. Ann. Thorac. Surg. 2004, 77, 81-86. [CrossRef]

63. Botta, L.; Buttazzi, K.; Russo, V.; Parlapiano, M.; Gostoli, V.; Di Bartolomeo, R.; Fattori, R. Endovascular Repair for Penetrating Atherosclerotic Ulcers of the Descending Thoracic Aorta: Early and Mid-Term Results. Ann. Thorac. Surg. 2008, 85, 987-992. [CrossRef] [PubMed]

64. Mestres, G.; Rodriguez, R.; Garcia-Madrid, C.; Montañà, X.; Burrel, M.; Cruz, L.F.; Flores, C.; Riambau, V. Endovascular treatment of penetrating aortic ulcers: Mid-term follow-up. Revista Española de Cardiología 2012, 65, 54-59. [CrossRef] [PubMed]

65. Patel, H.J.; Williams, D.M.; Upchurch, G.R.; Dasika, N.L.; Deeb, G.M. The challenge of associated intramural hematoma with endovascular repair for penetrating ulcers of the descending thoracic aorta. J. Vasc. Surg. 2010, 51, 829-835. [CrossRef]

66. Penetrating Aortic Ulcer Database: The Way to Know More. Available online: https://evtoday.com/articles/ 2014-nov/penetrating-aortic-ulcer-and-intramural-hematoma (accessed on 15 April 2020).

(C) 2020 by the authors. Licensee MDPI, Basel, Switzerland. This article is an open access article distributed under the terms and conditions of the Creative Commons Attribution (CC BY) license (http://creativecommons.org/licenses/by/4.0/). 